\title{
INTELLIGENS IMPRESSZIÓK TERE
}

\section{THE SPACE OF INTELLIGENT IMPRESSIONS}

\author{
Kósa Balázs ${ }^{1}$, Sódar Norbert ${ }^{2}$, Kovács Péter $^{3}$ \\ ${ }^{I}$ Pécsi Tudományegyetem Müszaki és Informatikai Kar Vizuális Ismeretek Tanszék \\ H-7624 Pécs Boszorkány u. 2. "B" Épület 341-es iroda; Telefon / Fax: +36-30- \\ 5399616 kosa.balazs@mik.pte.hu \\ ${ }^{2}$ PTE-MIK, H-6724 Szeged, Fürész u.7, norbert.sodar.nsarchitect@gmail.com \\ ${ }^{3} P T E-M I K$, kope.hun@gmail.com
}

\begin{abstract}
In the scope of this article is the presentation of the idea of Intelligent TALENT SPACE meaning the basis of architectural planning bearing an innovative technical attitude that suits to serve the future generations. „The intelligent house of the future" presented in this article is a good example for the innovative solutions of $\operatorname{Cog}$ InfoCom ${ }^{[1]}$.In the talent space planned by us, youngsters belonging to the $\mathrm{CE}$ generation ${ }^{[2]}$ might as well meet the most modern and forward-looking Science architectural notions and solutions as early as from the kindergarten years entering a Smart Home (Smart Home of Tomorrow) which we can start to handle as a big-size smart phone. By applying the Smart applications, the system reacts to the user of the flat, it is suitable for carrying out continuous psychological check-ups. In the sample home to be created for the Talent Space, the appearance of disruptive technologies in the higher education in engineering ${ }^{[3]}$ provides opportunities for realizing the most diverse ideas, whether it be predicting the dwellers' medical problems (e.g.: heart attack, epileptic seizure, ... etc.), observing incidental, unexpected accidents with the help of a central camera and sensors measuring the body temperature is feasable. According to our view, this intelligent space - due to its operational opportunities - completely suits to the CE generation's digital life and inspires the invention and realization of creative architectural solutions.
\end{abstract}

Keywords: architecture, technology, smart home, disruptive, talent space,

\section{Összefoglalás}

A cikk középpontjában a jövő generációinak kiszolgálásához illeszkedő újszerü mérnöki szemlélettel bíró építészeti tervezés megalapozását jelentő Intelligens TEHETSÉGTÉR gondolatának bemutatása áll. A cikkben bemutatásra kerülő „The intelligent house of the future” egy jó példa CogInfoCom ${ }^{[1]}$ újszerủ megoldásaira. Az általunk tervezett tehetségtérben a $\mathrm{CE}$ generációhoz ${ }^{[2]}$ tatozó fiatalok, akár az óvodás kortól találkozhatnak a legmodernebb és a jövőbe mutató Science építészeti elképzelésekkel, megoldásokkal egy olyan Smart Home-ba (Smart Home of tomorow) lépve, amit egy nagyra nőtt okostelefonként kezdhetünk el kezelni. A Smart megoldások alkalmazásával a rendszer reagál a lakás használójára, folyamatos pszchiológiai vizsgálatok elvégzésére alkalmas. A Tehetségtér számára kialakítandó minta otthonban disruptive technológiák müszaki felsőoktatásban való megjelenése ${ }^{[3]}$ a legkülönbözőbb ötletek megvalósítására nyílik lehetőség, akár a lakók orvosi problémáinak előre jelzésére is (pl.: szívinfarktus, epilepsziás roham... stb.), esetleges váratlan balesetek megfigyelése, központi kamera és testhőmérsékletet mérő szenzorok segítségével megvalósítható. Meglátásunk szerint ez az intelligens tér kezelési lehetőségeinél fogva teljes mértékben illeszkedik a CE generáció digitális életéhez, így inspirálja a kreatív építészeti megoldások kitalálását, megvalósítását.

Kulcsszavak: épitészet, technológia, intelligens otthon, disruptive, tehetségtér 


\section{Preambulum}

Dolgozatunk alulról építkezve elemzi a közösségeket és azok igényeit.

Célunk egy olyan intelligens TEHETSÉGTÉR létrehozása, ahol értő figyelemmel és környezettel segítjük már az óvodától az individumokat, hogy valamenynyi nyitott gondolkodású megtalálja saját tehetségterét és kiemelkedő teljesítményeket hozzon létre.

\subsection{A közösség és egyén viszonya}

A közösség és az egyén fogalma szétválaszthatatlanok egymástól. 2011-ben alakult b2 hallgatói csoportosulás erőssége, hogy a mérnöki, közgazdasági, bölcsész és müvészeti tudományok között álló szakemberek még komplexebb tudományterületekkel viszonyulnak a körülötte élökhöz. Szükségét érezzük tehát, hogy létrehozzunk egy olyan teret, ahol kreatív tudásukat hasznosítani tudják a benne tevékenykedők. Így fogalmazódott meg bennünk az, hogy megalkossuk a TEHETSÉGTÉR (Intelligens Impressziók Tere) fogalmát.

\subsection{A TEHETSÉGTÉR fogalma, magya- rázata}

A tehetségtér egy olyan tér, ahol a tudomány a napi élet részévé válhat. A gyerekek, diákok, együtt gondolkozhatnak, vitázhatnak, pozitív kicsengésü szakmai és közösségi együttmüködést kezdeményezhetnek. A disruptive technológiák integrálása a mérnöki képzésbe és annak előkészítését szolgáló Tehetségtér anyagába újszerü pedagógiai módszereket igényel. ${ }^{[1][2]} \mathrm{Az}$ általunk kidolgozott módszerben a Bohmféle dialógus alapgondolatait kívánjuk továbbfejleszteni.

\subsection{A tér}

Az építészet maga a téralkotás.

$\mathrm{Az}$ építészeti tér minőségi kialakításának érdekében meg kell értenünk a mai kor emberének (a potenciális megrendelőknek) gondolkodásmódját. $\quad \mathrm{Az}$ építészek kör- nyezetalakító tevékenységének egyik alapvetően elvárható követelménye a felelősségvállalás. Felelősségvállalás az épületekért, és az épületek társadalomra kivetülö pszichológiai és társadalmi következményeiért.

Ezen a gondolatmenetet alapul véve szeretnénk megalkotni egy olyan minőségi közösségi házat (teret), amely kiszolgálja a transzdiszciplinaritást, kiszolgálja a benne élőket és alkotókat, valamint megteremti a kényelmes és nyugodt munkakörnyezetet.

\subsection{Bohm-féle dialógus és az MI (mini mesterséges intelligencia)}

Bohm szerint a dialógus a társadalmikulturális változások alapvető eszköze, mindenfajta kreativitás forrása. Alkalmas arra, hogy leküzdje a ,csoportos elbutulásból” (Janis, id. Griffin, 2002) eredő öncenzúrát és ennek destruktív következményeit.

A TEHETSÉGTÉR mind Magyarországon, mind külföldön egyedülálló kezdeményezés, a tudományterületek együttmüködésében példamutató elképzelés lehet.

Célunk, hogy a résztvevők tervezett projektek mentén valamennyien átélhessék a felfedezés örömét, amely ösztönzően hat a tehetségük további kibontakoztatásában. A projekt célközönsége merjen bátran, kreatívan asszociálni, egymástól ma még teljesen független területeket összekapcsolni, akár "FORDÍTVA LÁTNI". Erre szolgálna az a központi számítógép, amely a világ minden területén kapcsolódási pontokat keres a hallgató témájához. Ezért létre szeretnénk hozni egy olyan teret, ahol minden a funkcionális és vizuális fejlődést segíti elő.

Mindez véleményünk szerint napjainkban nem valósítható meg a klasszikus mérnöki tudományok nélkül. Ezért kezdtük el vizsgálni gépészmérnök és villamosmérnök kollégákkal a SMART HOME-ok müködésének elvét. Mit is jelent számunkra az intelligens otthon? Különböző felszereltséggel bír, különböző funkciók jelennek meg benne, azonban egy közös van bennük: a 
felhasználók komfortérzetének kielégítése. Kijelenthető, hogy házainkat egy nagyra nőtt okostelefonként kezdtük el kezelni, amely folyamatosan bővülő repertoárral bír. Senki számára nem hat újként az, hogy a klimatizálást, árnyékolást, biztonságtechnológiát, világítástechnikát, multimédiás eszközeinket, vagy éppen a szellőztetést fizikai jelenlétünk nélkül is vezérelhetővé alakíthatjuk. Ezért szeretnénk mindezt egy kísérleti házban elérhetővé, fejleszthetővé tenni hallgatóink számára is.

\section{Intelligens ház}

\subsection{A külcsíny}

Amellett, hogy a már ismert technikai vívmányokat - szürkevíz hasznosítás, napkollektor, napelem, talajszonda, szél vizsgálat - felhasználja a ház, újdonságokkal is elóáll, ami amellett, hogy esztétikus funkcionálisan is fontos tényezőket tartalmaz. Amennyiben önálló ház valósul meg, akkor célunk egy olyan homlokzatburkolati elem létrehozása, amely teljes egészében kommunikálja az arra járóknak is, hogy ez nem egy szokványos otthon, hanem egy intelligens objektum. A burkolat maga lenne az árnyékoló rendszer is, amely reagál a napszaknak, időjárásnak, éghajlatnak megfelelően a környezetére. Úgy müködik majd, mint egy virág, amely nappal kinyílik, a fényt beengedi, estére azonban egy teljesen zárt, befelé kommunikáló és koncentrálódó világot hoz létre.

\subsection{A belbecs}

A bejárat leolvasó kártya és, vagy arcfelismerö rendszer segítségével nyílik, felismerve használóját- személyre szabott - és annak igényeit. Például azt a fényerősséget határozza meg, amit az illető elözetesen beállított...stb.

A kártya nemcsak a kulcs funkcióját tölti be, hanem a bankkártyáét és egyéb más fizető és adattároló eszközök szerepét. Mivel ujjlenyomattal müködik, ezért biztonságos, nem ad lehetőséget visszaélésekre.
A belső térben az összes ajtó alatt elhelyezkedő küszöb állítható magasságú, csakúgy, mint a vizesblokkoknál lévő - bidé, wc, mosdókagyló - szaniterek.

Telefonos applikáció segítségével, akár előre be is állítható és személyre szabható az épület, még hazaérkezésünk elött. Adott falak mozgatásával, nem elképzelhetetlen, hogy a ház belseje teljesen átalakul, amire a házigazda hazaér.

Terveink szerint létrehozunk olyan bútorokat, amelyek mérik a pulzust, elöre jelzik esetleges egészségügyi problémák lehetőségét.

\subsection{Mobilitás a belsőben}

Terveink szerint megvalósítunk egy olyan mozgatható térmodulátort, amely belsejében egy központi számítógép kerül elhelyezésre, a ház egyfajta agyaként.

Hőkamerák és infrakamerák elhelyezésével kiszüri a baleseteket és az illető életfunkcióit vizsgálja. Különböző illatok, szagok és színek létrehozására is képes, szem előtt tartva az egyén igényeit. A falba épített monitor segítségével az idősek könnyedén használhatják azokat a programokat hangvezérléssel -, amelyeket egy számítógép bonyolult kezelése miatt jelenleg nem feltétlenül használnak, pld. SKYPE, VIBER, FACEBOOK.

A fal, orvosi szempontból is fontos lehet, hiszen a nem kívánatos esetek időpontjában, automatikusan jelet ad le a legközelebbi kórház, rendőrség, tüzoltóság felé, jelezvén, valami olyan esemény zajlik éppen, ahol külső segítségre van szükség. Beépítésre kerülne egy gyógyszeradagoló is, amelyet ugyan egy nővér, vagy családtag adagol be, akár 3 hétre elöre is, de fizikálisan nem kell jelen lenni a nap minden szakaszában, hogy figyelmeztetve legyen a beteg gyógyszerének bevételére, hiszen a fal ekkor színt bocsájt ki, adott esetben hangot is és kinyílik az a fiók, amely tartalmazza a megfelelő gyógyszert. Jelzés kifelé csak abban az esetben megy, ha az illető nem vette be a tablettát. 


\section{Következtetések}

Az orvosokból, pszichológusokból, pedagógusokból és mérnökökből álló transzdiszciplináris kutatás lényege, hogy a SMART HOME-ok adta lehetőségeket felhasználva olyan foglalkoztató teret hozzunk létre, amely intelligenciája mentén a vizualitást, az automatizálást, valamint a komfortérzetet is pozitív irányba befolyásolja.

A szocializálódott ember vágya az, hogy különböző közösségekhez tartozzon, amelyek természetes vágyait képesek kielégíteni és ezeket a közösségeket, ha nem is mindig személyes, fizikális értelemben tesszük elérhetővé, de virtuálisan megoldást keresünk hozzá. Véleményünk szerint az intelligens terek nem pusztán automatizált tereket jelentenek, hanem jó tematikával ellátott válogatott impressziók sokasságát.

\section{Szakirodalmi hivatkozások}

[1]. P. Baranyi and A. Csapo: Definition and Synergies of Cognitive Infocommunications. Acta Polytechnica Hungarica, vol. 9, 67-83, 2012.

[2]. P. Baranyi, A. Csapo, Gy.Sallai: Cognitive Infocommunications (CogInfoCom). Springer International Publishing Switzerland 2015.

[3] I. Horvath, Z. Kvasznicza: Innovative engineering training - Today's answer to the challenges of the future, 2016 International Science Education Conference, Venice, Italy, 2016 IABC, 2016 IEC \& 2016 ISEC Proceedings, 466-472.

[4] I. Horvath, Z. Kvasznicza: Educational methods assisting the improvement of the competitiveness of Software Engineering Education, 9th European Conference on Software Architecture (ECSA 2015), Dubrovnik/Cavtat, Croatia, September 7-11 2015. 